\title{
傾斜機能材料
}

\author{
平井 敏雄
}

東北大学金属材料研究所， $\mathbf{\top} 980-77$ 仙台市青葉区片平2-1-1.

今から丁度 10 年前の 1985 年に, 宇宙往逗機用 の超高温熱遮蔽材の開発を目的として，わが国におい て世界に先駆けて提案された熱応力緩和型㑯斜機能材 料は，その後世界の注目を集め，各国で研究されるよ うになった．現在では，傾斜機能材料は，機械的機能 を主とした構造材料以外に，エネルギー関連材料，エ レクトロニクス材料, 光通信材料, 生体材料など幅広 い分野へも展開されるようになった。

わが国における傾斜機能材料の実用的な研究は，科 学技術庁の振興調整費「熱応力緩和のための傾斜機能 材料開発の基盤技術に関する研究」（19887 年度 1991 年度) および「傾斜構造形成によるエネルギ 一変換材料の開発に関する研究」（1993 年度〜

1995 年度)により行われてきた。一方, 傾斜機能 材料の基礎的研究に関しては，文部省は，1993 年 度科学研究費㭪助金総合研究 B「偭斜機能材料の創製 と諸性質」により大学関係者の組織化を図り，さらに 1995 年度には同じく総合研究 B「傾斜機能材料の 物理・化学」をスタートさせ，1996 年度から発足 する科学研究費補助金重点領域研究「傾斜機能材料の 物理・化学」（ 3 年間）のために調查研究を始めてい る.

本協会は, 他学協会に先駆けて，1989 年度に, 新機能材料分科会のなかに倾斜機能材料委員会を設置 し，「傾斜機能材料セミナー」を每年開催して傾斜機 能材料の研究に取り組んできた．講演特集としては， 1989 年度秋季大会, 1990 年度春季大会, 19 91 年度秋季大会, 1993 年度秋季大会に引き続き, 今回（1995 年度春季大会）が 5 回目である。これ らの主たる研究成果は，特集として本協会誌に掲载さ れている。

このたびの講演特集では，特別講演 1 件に加えて， 25 件の一般講演が行われた。講演には 70 名余りの
参加があり，討論あ活発に行われた，それらのうち， 11 件は論文としてこの特集に揭載されている。なお 本号に収録されなかった講演は，後日ぜひ本誌に一般 論文として投稿して頂きたいるのである.

特別講演では，宮本氏(阪大産研）は「傾斜機能材 料の世界的拡がり」と題して，世界各国における頃斜 機能材料の研究状況を紹介し，傾斜機能材料がわが国 の材料から世界の材料へと成長したことを述べた。

1996 年 10 月 21 日〜 24 日に筑波において第 4 回傾斜機能材料国際シンポジゥムが開催される予定 である。傾斜機能材料に関する優れた研究成果をここ の機会を利用して，ぜひご発表頂きたい。

\section{FIRST CIRCULAR AND CALL FOR PAPERS}

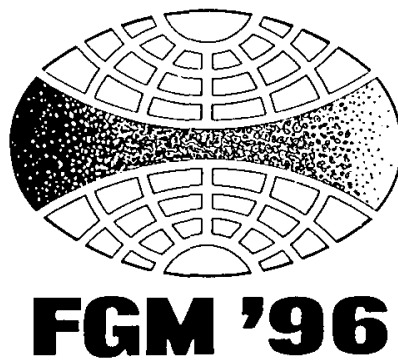

Fourth internationa: Symposium on Functionally Graded Matorials October 21-24, 1996

AIST Tsukuba Research Center, Tsukuba, Japan

Organized and Sponsored by The FGM Forum, The Society of Non-Traditional Technology

Supported by Beience and Techrology Agency 